\title{
DÜBLIN
}

Technological University Dublin

ARROW@TU Dublin

\section{Solvent stable microbial lipases: Current understanding and biotechnological applications}

\author{
Barry Ryan \\ Technological University Dublin, barry.ryan@tudublin.ie \\ Priyanka Priyanka \\ Technological University Dublin, D15127729@mydit.ie \\ Yeqi Tan \\ Technological University Dublin, d11124994@mydit.ie
}

See next page for additional authors

Follow this and additional works at: https://arrow.tudublin.ie/schfsehart

Part of the Biochemistry, Biophysics, and Structural Biology Commons, Biotechnology Commons, and the Chemistry Commons

\section{Recommended Citation}

Ryan, B. et al. (2018) Solvent stable microbial lipases: Current understanding and biotechnological applications, Biotechnol Lett. 2018 Dec 7. doi: 10.1007/s10529-018-02633-7

This Article is brought to you for free and open access by the School of Food Science and Environmental Health at ARROW@TU Dublin. It has been accepted for inclusion in Articles by an authorized administrator of ARROW@TU

Dublin. For more information, please contact

arrow.admin@tudublin.ie, aisling.coyne@tudublin.ie, gerard.connolly@tudublin.ie.

Funder: Technological University Dublin

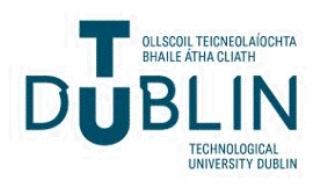




\section{Authors}

Barry Ryan, Priyanka Priyanka, Yeqi Tan, Gemma K Kinsella, and Gary T. Henehan

This article is available at ARROW@TU Dublin: https://arrow.tudublin.ie/schfsehart/309 


\section{Solvent stable microbial lipases: Current understanding and biotechnological applications}

2

Priyanka Priyanka*, Yeqi Tan*, Gemma K. Kinsella*, Gary T. Henehan*, Barry J. Ryan*\#

\section{Acknowledgments}

11 This work was supported by the Dublin Institute of Technology under the Fiosraigh Scholarship (PP and YT).

12

13 


\section{Abstract}

16 Objective: This review examines on our current understanding of microbial lipase solvent tolerance, with a specific

17 focus on the molecular strategies employed to improve lipase stability in a non-aqueous environment.

18 Results: It provides an overview of known solvent tolerant lipases and of approaches to improving solvent stability

19 such as; enhancing stabilising interactions, modification of residue flexibility and surface charge alteration. It shows

20 that judicious selection of lipase source supplemented by appropriate enzyme stabilisation, can lead to a wide

21 application spectrum for lipases.

22 Conclusion: Organic solvent stable lipases are, and will continue to be, versatile and adaptable biocatalytic

23 workhorses commonly employed for industrial applications in the food, pharmaceutical and green manufacturing

24 industries.

26 Keywords: industrial biocatalysis, lipase, lipase engineering, organic solvent stability, organic synthesis.

\section{1. Introduction}

29 The benefits of non-aqueous biocatalysis have strengthened the search for, and engineering of, solvent tolerant

30 enzymes. Non-aqueous reactions can assist the dissolution of hydrophobic compounds, drive reaction equilibria

31 from hydrolysis towards synthesis, have less undesirable side reactions (i.e. hydrolysis, polymerisation, racemisation)

32 and generally are unhampered by microbial contamination (Kumar et al. 2016). For biotransformation processes in

33 organic solvents to be more sustainable or "greener" than their chemical alternatives, they need to have higher

34 productivity, better selectivity and should involve less steps for the synthesis of the desired product (Tao \&

35 Kazlauskas 2011, Wenda et al. 2011).

36 Lipases belong to the triacylglycerol ester hydrolase family (EC 3.1.1.3) and have long been of interest in non37 aqueous synthesis (Sharma and Kanwar 2014). A major advantage of bacterial and fungal lipases, compared to plant 38 and animal lipases, is their thermal and organic solvent tolerance. Microbial lipases are more widely used than yeast 39 or fungal lipases since they are often more thermostable and offer higher catalytic activities (Salihu and Alam 2015).

40 This review will focus on the characteristics of lipases that contribute to their stability in organic solvents and on 41 stability-enhancing modifications of lipases. 


\section{2. Stability of lipases in organic solvents: structural features and interfacial activation}

44 The first lipase structures, from Rhizomucor miehei and human pancreas, were reported in the 1990s (Winkler et 45 al. 1990; Derewenda et al. 1992). By October 2018, a search for 'lipase structure' in the RCSB Protein Data Bank 46 (http://www.rcsb.org/pdb/) returned 273 hits. Structurally, all lipases fold in a similar fashion generating a 47 characteristic $\alpha / \beta$-hydrolase fold. This pattern contains parallel $\beta$-sheets surrounded by $\alpha$-helices. This fold also 48 gives rise to a catalytic triad composed of serine (Ser), histidine (His) and glutamate/aspartate (Glu/Asp) residues 49 along with several oxyanion-stabilizing residues (Kazlauskas, 1994). This active site is conserved in most lipases $50 \quad$ irrespective of size $(<1 \mathrm{kDa}$ to $>60 \mathrm{kDa})$.

52 A common characteristic of lipases is an increase in catalytic activity at a lipid water interface. This process, 53 known as interfacial activation, involves a structural rearrangement of the lipase from an inactive to an active 54 conformation. First identified in M. miehei lipase, the process is initiated by exposing a large hydrophobic area 55 around the active site (Brady et al. 1990). The exposed hydrophobic area allows the anchoring of the lipase at the 56 water/lipid interface thereby initiating catalysis. This resistance to denaturation at the water/lipid interface may 57 account for lipase stability in organic solvents. The structural changes at the water/lipid interfaces typically 58 involve a lid structure. The lid domain of lipases is amphipathic, having a hydrophobic and a hydrophilic side: in 59 water the hydrophilic side of the lid faces the solvent while the hydrophobic side is directed towards the active site 60 in a "closed" conformation. At the water/lipid interface the hydrophobic face becomes exposed allowing substrate 61 access - the "open" conformation (Khan et al. 2017). This lid movement also changes the orientation of oxyanion62 stabilizing residues to promote catalysis (Fischer et al. 2000). Lipase lid structures differ in terms of the position 63 and number of the surface loops. Smaller lipases (e.g. Rhizomucor miehei) form the lid using a single $\alpha$-helix 64 while larger lipases (e.g. Candida rugosa) form the lid using two $\alpha$-helices (see Figure One; Kazlauskas 1994b).

65 The activity of lipases in certain environments, e.g. in solvents, is dependent on the prevalence of the relevant 66 conformation. Previous studies have shown that lid opening can be induced in an organic solvent (Maiangwa et al. 67 2017; Adlercreutz 2013). The efficiency of interfacial activation varies in different solvents (Abuin et al. 2007). 68 Lipases show other changes in secondary structure in organic solvents. Lipase A from Candida Antarctica, for 69 example, shows increased $\alpha$-helical content following acetonitrile or acetone exposure and this change is 
correlated with changes in hydrolytic activity (Yang et al. 2012). Significant research has focused on correlating the conformational changes of lipases in organic solvents with catalytic activity (Benkovic and Hammes-Schiffer 2003). The structural integrity of lipases in solvents has been probed by X-ray crystallography, circular dichroism (CD; Pelton and McLean 2000) and by nuclear magnetic resonance (NMR; Eppler et al. 2006; Kumar et al. 2014) often coupled with modelling and molecular dynamics simulation (YooPark et al. 2013). It is worth noting, however, that organic solvents can also cause denaturation and deactivation of lipases. Moreover, some solvents can compete for substrate binding and thus act as lipase inhibitors (Dror et al. 2015; Grosch et al. 2017). Conversely, Zaks and Klibanov (1984) noted the importance of water for lipase activity through formation of noncovalent and hydrogen bonds with the enzyme. Water provides stability through a hydration shell, which protects it from direct contact with destabilising solvent (Díaz-García and Valencia-González 1995; Halling 1997). Loss of water molecules from the enzyme surface gives direct access to the solvent, thus disrupting its inter-, and intra-, molecular structure and provides rationale for solvent stable lipases (Schulze and Klibanov 1991; Dror et al. 2015).

\section{3. Solvent Stable Lipase Sources}

84 Many solvent stable lipases have been reported (see Table 1). For example, Pseudomonas aeruginosa AAU2 lipase 85 is stable in organic solvents with a $\log \mathrm{P} \geq 3.1$ and even after 24 hours of incubation retains more than $70 \%$ of its activity (Bose and Keharia 2013). Similarly, a lipase from Streptomyces sp. CS133 was stable in 25\% (v/v) $n$ -

87 Hexane $(\log \mathrm{P}=3.5)$ and octane ( $\log \mathrm{P}=4.9$; Mander et al. 2012) for 48 hours. In general, polar organic solvents are

88 harsher on lipases than non-polar solvents. Polar organic solvents can cause enzyme deactivation by hydrogen bond 89 disruption and by stripping the enzyme's protective hydration shell. However, a few lipases, for example a lipase 90 from Bacillus sphaericus MTCC 7542, were highly stable in both polar and non-polar organic solvents with a 91 residual activity of $80-95 \%$ in all solvents even after $12-\mathrm{hr}$ of incubation (Tamilarasan and Kumar 2012). Some

92 lipases are stable in non-polar organic solvents $(\log \mathrm{P} \geq 2)$, even after 7 days of incubation (e.g. Stenotrophomonas 93 maltophilia CGMCC 4254 lipase). Acinetobacter radioresistens CMC-1 and Acinetobacter EH 28 lipases have 94 higher stability and activity in $30 \%(\mathrm{v} / \mathrm{v}) n$-Hexane, dimethyl sulfoxide (DMSO) and acetone than in $15 \%$ of the 95 same solvents, indicating solvent activation (Ahmed et al. 2010). A lipase from Burkholderia ambifaria YCJ01 was 96 noted to be stable for 60 days in a number of hydrophilic and hydrophobic solvents $(25 \% \mathrm{v} / \mathrm{v})$ and retained $100 \%$ 97 activity in $25 \%(\mathrm{v} / \mathrm{v})$ ethanol and $80 \%$ activity in $25 \%(\mathrm{v} / \mathrm{v})$ acetonitrile, even after 30 days (Yao et al. 2013). 


\section{4. Improving organic solvent stability of lipases: random mutation and rational approaches}

101 Exploiting our growing knowledge of lipase structure/function/stability relationships, in conjunction with protein engineering, can improve the catalytic properties of lipases in solvents (Villeneuve et al. 2000). A random mutation

103 approach is useful when improving lipases when there is minimal structural information (Cobb et al. 2013). With

104 the advent of computational modelling and molecular dynamic simulations, solvent tolerance enhancement from

105 random mutation experiments can be understood at a structural level (Park, et al. 2013). In general, stabilising

106 mutations may be categorised as: those based on increasing the stabilising interactions of surface residues, those 107 reducing the flexibility of surface residues, and those changing the enzyme surface charge (see Table 2).

\section{Enhanced stabilising interactions}

110 The importance of stabilising interactions in protein stability has long been established as one of the "rules of 111 thumb' for protein engineering and the selection of target residues. Typical guiding principles include avoiding 112 changes to residues that contribute to stabilising interactions or residues involved in the formation of secondary 113 protein structure or those that might affect the formation of the active site (Yang et al. 2002). Based on the idea that

114 the action of a solvent (stabilising or destabilising) on the protein can be defined by the balance between its 115 preferential affinity for water or solvent (Timasheff 1993), many lipase engineering studies have involved mutation 116 of surface residues.

117 For example, a lipase variant from Pseudomonas sp. KWI-56, which was found to be $40 \%$ more stable in $80 \%(\mathrm{v} / \mathrm{v})$ 118 DMSO than wild type, had only a single surface residue mutation (V304A; Nakano et al. 1998). Similarly, a 119 G157R mutation in Pseudomonas aeruginosa LST-03 lipase introduced additional bonds that promoted salt bridge 120 and H-bond formation. Another example showed that a single S194R mutation in Pseudomonas aeruginosa LST12103 could introduce new hydrogen bonds that resulted in the lipase being more stable in several solvents (Kawata 122 and Ogino 2009, 2010). A methanol stable lipase variant from Proteus mirabilis was found to have mutations that 123 introduced new side chain interactions (L64I) and novel H-bond formation (A70T and R33T). Additionally, G202E, 124 K208N, G266S mutations are close to a $\mathrm{Ca}^{2+}$ binding site important for lipase stability. G266S introduced a new 125 interaction with water and a residue that coordinates $\mathrm{Ca}^{2+}$ (Korman et al. 2013). A methanol stable variant of 
126 Geobacillus stearothermophilus Lipase T6 (see Figure One) was found to have mutations that enabled the 127 formation of hydrogen bonds with surface water (A269T, R374W) and a widened hydrogen bond network to 128 enable more direct contact with the $\mathrm{Zn}^{2+}$ coordinating residue (H86Y, Dror et al. 2014; Dror et al. 2015).

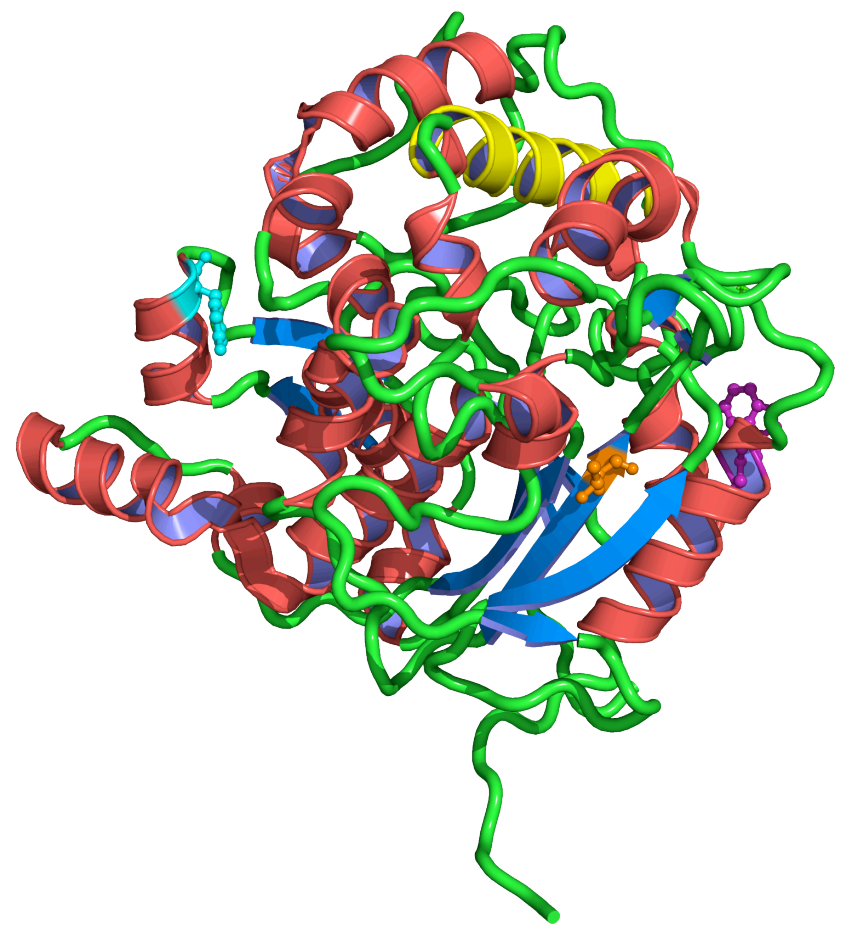

130 Fig. 1 Methanol stable lipase variant H86Y/A269T/R374W from Geobacillus stearothermophilus T6 (PDB: 4X85)

131 (Gihaz et al. 2018). The lid residues, F177-A192, are shown in yellow. The mutated residues are highlighted as 132 H86Y (in cyan), A269T (in orange) and R374W (in purple). The image was generated using Pymol (DeLano 2018)

\section{Residue flexibility}

135 The flexibility of protein residues is often associated with enzyme stability (McAuley \& Timson, 2016). It has been

136 suggested that the stability of lipases is due to their conformation being more rigid in organic solvents (Sharma \& 137 Kanwar, 2014). This was supported by several studies including a DMSO-stable Bacillus substilis lipase variant 138 with an overall increased flexibility due to a single mutation to a more conformationally flexible residue (A269S), 139 resulting in a less stable variant than the more rigid wild-type residue (Yedavalli \& Madhusudhana Rao, 2013). The 140 increase in rigidity associated with a network of intramolecular interactions, such as the extension of hydrogen 141 bonds on the lipase surface, can prevent solvent penetration (Dror et al. 2014, 2015) and prevent protein 142 denaturation (Reetz et al. 2006). 
143 An increase in stabilising interactions has also been reported when targeting residue flexibility for improving 144 Candida antarctica lipase B (CalB) stability in methanol (Park, et al. 2013). In this case, all the stabilising 145 mutations were involved in the formation of additional hydrogen bonds with surface water (A8T, A92E, N97Q) or 146 had shorter hydrogen bond distances (T245S). By contrast, mutations (e.g. T244D) that reduced the number of 147 hydrogen bonds with water were linked to a reduced stability in methanol.

148 The flexibility of protein residues can be characterised using the B-factor value or Root Mean Square Deviation 149 (RMSD) value. The B-factor, or the Debye Waller value, is used in crystallography to rate the flexibility of a residue 150 in a protein structure: a higher value corresponds to greater flexibility (Reetz et al. 2006). This value represents the 151 degree of elastic scattering caused by positional disorder, or the thermal motion, of an atom and hence a higher 152 mobility of a protein residue is indicated by a high B-factor (Yuan et al. 2005). The selection of a residue based on 153 its B-factor is known as a B-factor iterative test (B-FIT, Illanes et al. 2012) and is commonly used to guide enzyme 154 thermostability enhancement (Wen et al. 2013; Kumar et al. 2014; Augustyniak et al. 2012). In this approach, 155 residues with a high B-factor score were selected as the target for mutation. Using this approach, Reetz and 156 colleagues (2010) successfully improved the stability of a lipase from Bacillus subtilis in polar organic solvents by 157 mutating residues with the highest $\mathrm{B}$ factors to enhance the rigidity of the lipase.

158 Additionally, molecular dynamics simulations (MDS) are used to understand the dynamic nature of lipases in 159 different environments. The relative flexibility of each individual residue in MDS is typically represented by Root 160 Mean Square Deviation (RMSD) and Root Mean Square Fluctuation (RMSF) values. RMSD is a measure of 161 deviation from the initial structure whereas RMSF is a measure of deviation from an average structure (Benson and 162 Daggett 2012). Employing this approach, Park and colleagues (2013) rationalised the selection of residues with high 163 RMSD as solvent affecting sites and the subsequent mutations (A8T, A92E, N97Q, T244D and T245S) enhanced 164 CalB methanol stability and also had lower RMSD values in methanol.

165 Despite finding that greater lipase rigidity increases solvent stability, the decrease in enzyme flexibility observed in 166 organic solvents is thought to be related to the corresponding decline in catalytic activity. The more rigid structure of 167 LipA from Candida antarctica in ethyl esters is attributed to higher $\beta$-sheet content resulting in diminished catalytic 168 activity (Yang et al. 2012). Yagonia and colleagues (2015) incorporated such considerations when improving CalB 169 lipase stability and activity in methanol. By considering the catalytic orientation of CalB lipase, the structure was 170 divided into a solvent affecting region and substrate-binding region for flexibility modulation based on B-factor and 
171 RMSD analysis. Mutations which increased rigidity in the solvent affecting region (A92E and T245S) showed 172 higher methanol stability, but were less catalytically active, than the variants with activity enhancing mutations

173 (V139E and A151D) and vice versa. The combination of both mutations resulted in mutants (V139E, A92E and

174 V139E, T245S) that were more active and stable in presence of methanol (Yagonia et al. 2015).

175

\section{Surface charge and polarity}

177 The effect of the polarity of organic solvent on surface charge has been correlated with lipase activity and stability 178 (Iyer and Ananthanarayan 2008; Chakravorty et al. 2012; Jain and Mishra 2015)). Solvents with low polarity cause

179 the dispersal of enzyme hydrophobic domains due to solvent penetration, resulting in enzyme inactivation (Ogino 180 and Ishikawa 2001). Conversely, the formation of a hydrated ion network, by charged amino acids, maintains the 181 stability of lipases in organic solvents by preventing protein aggregation via repulsing electrostatic charges (Jain and

182 Mishra 2015). In a set of random mutation studies by Kawata and colleagues (2009, 2010), Pseudomonas 183 aeruginosa LST-03 lipase variants selected for stability in solvents were noted to possess mutations of surface 184 residues (S164K, Y188F, L145H) that prevented penetration of the solvent into the protein. The increase in pI, due 185 to the mutations (S164K, S211R, G157R, S194R, D209N, L145H), repulsed the basic organic solvent molecules 186 through an ion repulsion interaction. In a comparable study, the mutation of lid residues to more hydrophobic 187 residues (F146L, I289T) changed the accessibility of solvents to the active site of a lipase from Pseudomonas sp. 188 KWI-56 (Nakano et al. 1998).

189 Yedavalli and collegues (2013) improved the stability of lipase (LipA) from Bacillus substilis in DMSO by 190 modifying the loop secondary structure of the enzyme. In this case, the stable mutants had a similar secondary 191 structure to the wild type, but with a more polar surface. Monsef Shokri and co-workers (2014) targeted a loop on 192 the protein surface to improve the stability of Pseudomonas sp. lipase in non-aqueous solvent, by using the strategy 193 of hydrophobic residue substitution (Arnold 1990). The variants that were more stable in hydrophilic organic 194 solvents had hydrophobic mutations at position 219 (N219A, N219I, N219L), resulting in increased lipase rigidity. 195

TABLE 2 HERE 
198 5. Selected applications of Organic Solvent Stable Lipases by industry

199 Solvent compatible lipases are in use in the food, (bio)pharmaceutical and environmental industries (Ahmed et al.

200 2010). Selected applications in these industries are discussed below.

The world flavour and fragrance market was \$22 billion (USD) in 2011 and has been increasing at a rate of 5.6\%

204 annually (Badgujar et al. 2016). Although the isolation and extraction of flavour esters from natural sources is 205 expensive, consumers prefer products with a 'natural' label (Ahmed et al. 2010). Therefore, alternatives to chemical 206 synthesis of flavour esters, including alternative production technologies such as esterification by solvent stable 207 lipase, have gained attention (Matte et al. 2016 and see Table 3).

TABLE 3 HERE

\section{Pharmaceutical Industry: Regio- and Stereo-selective Resolution}

212 Lipases are widely used for the kinetic resolution of compounds (Xun et al. 2013). The regioselectivity of lipases 213 has been exploited for the resolution of racemic alcohols and kinetic resolution of racemic mixtures of compounds

214 such as flurbiprofen (C. antartica lipase Novozyme ${ }^{\circledR}$ 435) and N-hydroxymethyl vince lactam (Mucor meihei lipase; 215 Xun et al. 2013). Interestingly, lipase resolution has also been explored in the production of herbicides 216 (phenoxypropionate) by the resolution of 2-halopropionic acids and esterification of (S)-isomers in butanol and 217 hexane (Hasan et al. 2006).

218 Lipase regioselectivity has been used for the synthesis of compounds that are difficult to synthesize by chemical 219 methods (Miyazawa et al. 2014). Non-ionic and biodegradable sugar esters have extensive applications in detergents, 220 pharmaceutical and oral care products. Their conventional production, involving chemical sugar and fatty acid 221 esterification, is difficult due to poor regioselectivity and the low organic solvent solubility of sugars. This 222 esterification was achieved by immobilized lipase B from Candida Antarctica (Novozyme ${ }^{\circledR} 435$ ) in DMSO and 223 acetone $(1: 10 \mathrm{v} / \mathrm{v})$. This dual solvent environment has been used for the production of a xylose caproate ester with 224 64\% yield (Abdulmalek et al. 2016). Various other precursor molecules required for the manufacturing of a range of 225 pharmaceutical and agrochemical products are currently synthesised by lipases in solvents (see Table 4). 


\section{Environmental applications: Biodegradable polymer synthesis and recycling}

230 In recent times, much attention has focused on polymer research due to their increased use in biomedical research,

231 food packaging and agricultural industries. However, the disposal of these polymers is a critical environmental issue, 232 and has led to the development of biodegradable polymers (e.g. polyesters) as an alternative to traditional plastics 233 (Banerjee et al. 2014). Solvent stable lipases have been widely used as catalysts for the synthesis of such 234 biodegradable polyesters (Barrera-rivera \& Flores-carreón 2012 and see Table 5). The lipase from Candida 235 antarctica lipase B (CalB) is the most common catalyst used for polyester synthesis (Chen et al. 2008).

236 The production of biodegradable polyesters plays a significant role in a green environmental approach to packaging;

237 however, recycling is equally important from an environmental perspective. A wide range of aromatic and aliphatic 238 polyesters including poly(ethylene terephthalate), poly(butylene succinate), poly ( $\beta$-caprolactone) and poly(lactic) 239 acids are used in the production of medical biomaterials such as surgical sutures and reinforcing plates (Kobayashi, 240 2010). Chemical recycling has limited applications due to its high-energy demand, both in terms of temperature and 241 pressure. However, degradation of biopolymers by enzymatic processes can occur with a lower energy requirement 242 and in milder conditions (see Table 5 for relevant examples). Moreover, chemical based recycling cleaves polymers 243 randomly, generating varying molecular weight oligomers while lipase catalyzed degradation involves cleaving the 244 amorphous regions of a polymer first, followed by its crystalline regions, consistently resulting in oligomers with 245 lower molecular weights (Banerjee et al. 2014). The lipase from Candida antarctica has been successfully utilised to 246 degrade poly $\left(\beta\right.$-caprolactone; PCL) in dry toluene at $60^{\circ} \mathrm{C}$. This 'one-pot degradation-polymerisation' reaction 247 successfully recycled poly( $\beta$-caprolactone; Kobayashi et al. 2000). Although lipases can hydrolyse poly( $\beta$ 248 caprolactone) in aqueous solution; the low solubility of hydrophobic PCL in water means that, solvents are generally 249 used for their degradation (Aris et al. 2016).

TABLE 5 HERE 


\section{6. Considerations in the development of organic solvent stable lipases for industrial application}

254 Currently, industrial biocatalysis requires lipases for existing and emerging industries. New lipases can be delivered

255 via biodiscovery or through improving existing lipase properties by protein engineering. Despite the increasing

256 number and availability of organic solvent stable lipases there is a lack of translation of lab scale biocatalysis to

257 industry scale. Optimising an enzyme for use in a given application is challenging as it is difficult to make the

258 biocatalytic operational space (e.g. temperature, $\mathrm{pH}$, pressure etc.) as wide as the chemical counterpart. Enzymes are

259 prone to denaturation and deactivation under extreme processing conditions (Tufvesson et al. 2013; Ringborg and

260 Woodley 2016). In reactions involving organic solvents there are several thermodynamic constraints including;

261 interaction with the enzyme, substrate solubility and enzyme solubility (Grosch et al. 2017). This results in the need

262 to understand the effective concentration of substrate available to the enzyme, competitive inhibition by the organic

263 solvent, transition state stabilisation (Dutta Banik et al. 2016), as well as steric effects (Wang et al. 2016). In the past,

264 biodiscovery and engineering of existing organic solvent lipases commenced without a defined target reaction;

265 however, now these thermodynamic constraints are key drivers in the enzyme selection procedure for industrial scale

266 biocatalysis (Ringborg and Woodley 2016). It is prudent to identify the organic solvent effects; such as solvation of

267 substrate, inhibition by solvent molecule, and water activity, on catalysis (Sandoval et al. 2001; Kulschewski et al.

268 2013; Grosch et al. 2017).

269

\section{$270 \quad 7 . \quad$ Conclusion and Future Directions}

271 Lipases continue to be an important biocatalyst in the food, pharmaceutical, and chemical industries (De Godoy

272 Daiha et al. 2015). Previous lipase engineering efforts have demonstrated that, through engineering approaches, 273 organic solvent stability can be achieved. The utility of lipases in biocatalysis depends on finding a balance between

274 enzyme rigidity and catalytic activity for many applications. A recent study looked at filling lipase solvent tunnels

275 with aromatic interactions to improve lipase stability in methanol, with the results demonstrating a stabilisation of 81-

276 fold compared with wild-type (Gihaz et al. 2018). This rational approach could be extended to other lipases for

277 stabilization in organic solvents.

278 The use of novel solvent systems such as ionic liquids or deep eutectic solvents appears to offer promising 279 alternatives to traditional organic solvents. Recently, Brogan and colleagues (2018) reported that the combination of 280 chemical modification and ionic liquids produced a highly robust glucosidase that displayed "solvent induced 
substrate promiscuity" and activity at temperatures up to $137^{\circ} \mathrm{C}$. Thus, through a synergistic combination of enzyme modification and solvent choice the biocatalytic capability of enzymes was enhanced. It would be of interest to explore whether such chemical modification might lead to similar stabilisation of lipases in solvents.. It is clear that

284 the drive for more sustainable catalysis will provide an impetus for this field in the coming years.

\section{Compliance with Ethical Standards}

287 Funding: This work was supported by the Dublin Institute of Technology under the Fiosraigh Scholarship (PP and 288 YT).

289 Conflict of Interest: The authors declare that they have no conflict of interest.

290 Ethical Approval: This article does not contain any studies with human participants or animals performed by any of 291 the authors

292 Authorship: Conceived study (PP, YT, GKK, GTH, BJR), Performed research (PP, YT), Analyzed data (PP, YT), 293 Contributed methods (GKK, GTH, BJR), Wrote the paper (PP, YT, GKK, GTH, BJR).

294 Data Availability: The datasets generated during and analysed during the current study are available from the 295 corresponding author on reasonable request.

\section{References:}

Abdulmalek E, Hamidon NF, Abdul Rahman MB (2016) Optimization and characterization of lipase catalysed synthesis of xylose caproate ester in organic solvents. J Mol Catal B Enzym 132:1-4. doi: 10.1016/j.molcatb.2016.06.010

Abuin E, Lissi E, Jara P (2007) Effect of the organic solvent on the interfacial micropolarity of AOT -water reverse micelles. J Chil Chem Soc 52:1082-1087. doi: 10.4067/S0717-97072007000100006

Adlercreutz P (2013) Immobilisation and application of lipases in organic media. 42:6406-6436. doi: $10.1039 / \mathrm{c} 3 \operatorname{cs} 35446 f$

Ahmed EH, Raghavendra T, Madamwar D (2010) An alkaline lipase from organic solvent tolerant Acinetobacter sp. EH28: Application for ethyl caprylate synthesis. Bioresour Technol 101:3628-3634. doi: 
10.1016/j.biortech.2009.12.107

Aris MH, Annuar MSM, Ling TC (2016) Lipase-mediated degradation of poly-??-caprolactone in toluene: Behavior and its action mechanism. Polym Degrad Stab 133:182-191. doi: 10.1016/j.polymdegradstab.2016.08.015

Arnold FH (1990) Engineering enzymes for non-aqueous solvents. Trends Biotechnol 8:244-249. doi:

314 Augustyniak W, Brzezinska AA, Pijning T, et al (2012) Biophysical characterization of mutants of Bacillus subtilis

315 lipase evolved for thermostability: Factors contributing to increased activity retention. Protein Sci 21:487-497.

316 doi: $10.1002 /$ pro.2031

317 Badgujar KC, Pai PA, Bhanage BM (2016) Enhanced biocatalytic activity of immobilized Pseudomonas cepacia 318 lipase under sonicated condition. Bioprocess Biosyst Eng 39:211-221. doi: 10.1007/s00449-015-1505-5

319 Banerjee a., Chatterjee K, Madras G (2014) Enzymatic degradation of polymers: a brief review. Mater Sci Technol 30:567-573. doi: 10.1179/1743284713Y.0000000503

321 Barrera-rivera KA, Flores-carreón A (2012) Synthesis of Biodegradable Polymers Using Biocatalysis with Yarrowia lipolytica Lipase Chapter 28 Synthesis of Biodegradable Polymers Using Biocatalysis with Yarrowia lipolytica Lipase. doi: 10.1007/978-1-61779-600-5

324 Benkovic SJ, Hammes-Schiffer S (2003) A Perspective on Enzyme Catalysis. Science (80- ) 301:

325 Benson NC, Daggett V (2012) A comparison of multiscale methods for the analysis of molecular dynamics 326 simulations. J Phys Chem B 116:8722-8731. doi: 10.1021/jp302103t

327 Bose A, Keharia H (2013) Production, characterization and applications of organic solvent tolerant lipase by Pseudomonas aeruginosa AAU2. Biocatal Agric Biotechnol 2:255-266. doi: 10.1016/j.bcab.2013.03.009

329 Brady L, Brzozowski AM, Derewenda ZS, et al (1990) A serine protease triad forms the catalytic centre of a

331 Brogan APS, Bui-Le L, Hallett JP.Nat Chem. 2018 Non-aqueous homogenous biocatalytic conversion of polysaccharides in ionic liquids using chemically modified glucosidase Aug;10(8):859-865. doi:

334 Chakravorty D, Parameswaran S, Dubey VK, Patra S (2012) Unraveling the rationale behind organic solvent 335 stability of lipases. Appl Biochem Biotechnol 167:439-461. doi: 10.1007/s12010-012-9669-9

336 Chen B, Hu J, Miller EM, et al (2008) Candida antarctica Lipase B chemically immobilized on epoxy-activated 
micro- and nanobeads: Catalysts for polyester synthesis. Biomacromolecules 9:463-471. doi: $10.1021 / \mathrm{bm} 700949 \mathrm{x}$

Cobb RE, Chao R, Zhao H (2013) Directed Evolution: Past, Present and Future. AIChE J 59:1432-1440. doi:

$$
\text { 10.1002/aic. } 13995
$$

341 De Godoy Daiha K, Angeli R, De Oliveira SD, Almeida RV (2015) Are lipases still important biocatalysts? A study of scientific publications and patents for technological forecasting. PLoS One 10:e0131624. doi: 10.1371/journal.pone.0131624

345 Derewenda ZS, Derewenda U, Dodson GG (1992) The crystal and molecular structure of the Rhizomucor miehei

Dror A, Shemesh E, Dayan N, Fishman A (2014) Protein engineering by random mutagenesis and structure-guided triacylglyceride lipase at 1.9 Å resolution. J Mol Biol 227:818-839. doi: 10.1016/0022-2836(92)90225-9

Díaz-García ME, Valencia-González MJ (1995) Enzyme catalysis in organic solvents: a promising field for optical biosensing. Talanta 42:1763-1773

Dror A, Kanteev M, Kagan I, et al (2015) Structural insights into methanol-stable variants of lipase T6 from Geobacillus stearothermophilus. Appl Microbiol Biotechnol 99:9449-9461. doi: 10.1007/s00253-015-6700-4

354 Dutta Banik S, Nordblad M, Woodley JM, Peters GH (2016) A Correlation between the Activity of Candida antarctica Lipase B and Differences in Binding Free Energies of Organic Solvent and Substrate. ACS Catal consensus of Geobacillus stearothermophilus lipase T6 for enhanced stability in methanol. Appl Environ Microbiol 80:1515-1527. doi: 10.1128/AEM.03371-13

F. K. Winkler, D’Arcy A, Hunziker W (1990) Structure of human pancreatic lipase. Nature 3:771-774

361 Fischer M, Peiker M, Thiele C, Schmid RD (2000) Lipase engineering database Understanding and exploiting

364 Gihaz S, Kanteev M, Pazy Y, Fishman A (2018) Filling the void: Introducing aromatic interactions into solvent 
tunnels towards lipase stability in methanol. Appl Environ Microbiol. doi: https://doi.org/10.1128/AEM.02143-18

367 Grosch JH, Wagner D, Nistelkas V, Spie?? AC (2017) Thermodynamic activity-based intrinsic enzyme kinetic 368 sheds light on enzyme-solvent interactions. Biotechnol Prog 33:96-103. doi: 10.1002/btpr.2401

369 Halling PJ (1997) Predicting the behaviour of lipases in low-water media. Biochem Soc Trans 25:170-4

370 Hasan F, Shah AA, Hameed A (2006) Industrial applications of microbial lipases. Enzyme Microb Technol 39:235371 251. doi: $10.1016 /$ j.enzmictec.2005.10.016

372 Illanes A, Cauerhff A, Wilson L, Castro GR (2012) Recent trends in biocatalysis engineering. Bioresour Technol $373 \quad$ 115:48-57. doi: 10.1016/j.biortech.2011.12.050

374 Iyer P V., Ananthanarayan L (2008) Enzyme stability and stabilization-Aqueous and non-aqueous environment. 375 Process Biochem 43:1019-1032. doi: 10.1016/j.procbio.2008.06.004

376 Jain D, Mishra S (2015) Multifunctional solvent stable Bacillus lipase mediated biotransformations in the context of 377 food and fuel. J Mol Catal B Enzym 117:21-30. doi: 10.1016/j.molcatb.2015.04.002

378 Kawata T, Ogino H (2009) Enhancement of the organic solvent-stability of the LST-03 lipase by directed evolution. 379 Biotechnol Prog 25:1605-1611. doi: 10.1002/btpr.264

380 Kawata T, Ogino H (2010) Amino acid residues involved in organic solvent-stability of the LST-03 lipase

381 Kazlauskas RJ (1994a) Elucidating structure-mechanism relationships in lipases: Prospects for predicting and 382 engineering catalytic properties. Trends Biotechnol 12:464-472. doi: 10.1016/0167-7799(94)90022-1

383 Kazlauskas RJ (1994b) Elucidating structure-mechanism relationships in lipases: Prospects for predicting and engineering catalytic properties. Trends Biotechnol 12:464-472. doi: 10.1016/0167-7799(94)90022-1

385 Khan FI, Lan D, Durrani R, et al (2017) The Lid Domain in Lipases: Structural and Functional Determinant of 386 Enzymatic Properties. Front Bioeng Biotechnol 5:1-13. doi: 10.3389/fbioe.2017.00016

387 KOBAYASHI S (2010) Lipase-catalyzed polyester synthesis - A green polymer chemistry. Proc Japan Acad Ser B 86:338-365. doi: 10.2183/pjab.86.338

389 Kobayashi S, Uyama H, Takamoto T (2000) Lipase-Catalyzed Degradation of Polyesters in Organic Solvents. A 390 New Methodology of Polymer Recycling Using Enzyme as Catalyst. 3-5

391 Korman TP, Sahachartsiri B, Charbonneau DM, et al (2013) Dieselzymes: development of a stable and methanol 392 tolerant lipase for biodiesel production by directed evolution. Biotechnol Biofuels 6:70. doi: 10.1186/1754- 
$6834-6-70$

394 Kulschewski T, Sasso F, Secundo F, et al (2013) Molecular mechanism of deactivation of C. antarctica lipase B by methanol. J Biotechnol 168:462-469. doi: 10.1016/j.jbiotec.2013.10.012

Kumar A, Dhar K, Kanwar SS, Arora PK (2016) Lipase catalysis in organic solvents: advantages and applications. Biol Proced Online 18:2. doi: 10.1186/s12575-016-0033-2

Kumar V, Yedavalli P, Gupta V, Rao NM (2014) Engineering lipase A from mesophilic Bacillus subtilis for activity at low temperatures. Protein Eng Des Sel 27:73-82. doi: 10.1093/protein/gzt064

Maiangwa J, Mohamad Ali MS, Salleh AB, et al (2017) Lid opening and conformational stability of T1 Lipase is mediated by increasing chain length polar solvents. PeerJ 5:e3341. doi: 10.7717/peerj.3341

Mander P, Cho SS, Simkhada JR, et al (2012) An organic solvent - tolerant lipase from Streptomyces sp . CS133 for enzymatic transesterification of vegetable oils in organic media. Process Biochem 47:635-642. doi: 10.1016/j.procbio.2012.01.003

Matte CR, Bordinhaõ C, Poppe JK, et al (2016) Synthesis of butyl butyrate in batch and continuous enzymatic reactors using Thermomyces lanuginosus lipase immobilized in Immobead 150. J Mol Catal B Enzym 127:67-75. doi: 10.1016/j.molcatb.2016.02.016

McAuley M, Timson DJ (2016) Modulating Mobility: a Paradigm for Protein Engineering? Appl. Biochem.

Monsef Shokri M, Ahmadian S, Akbari N, Khajeh K (2014) Hydrophobic substitution of surface residues affects Biotechnol. 181:1-8

Miyazawa T, Hamada M, Morimoto R, Maeda Y (2014) Candida antarctica lipase B-mediated regioselective acylation of dihydroxybenzenes in organic solvents. Tetrahedron 71:3915-3923. doi: 10.1016/j.tet.2015.04.033 lipase stability in organic solvents. Mol Biotechnol 56:360-368. doi: 10.1007/s12033-013-9716-y

Nakano H, Ide Y, Tsuda T, et al (1998) Improvement in the organic solvent stability of pseudomonas lipase by random mutation. In: Annals of the New York Academy of Sciences. Blackwell Publishing Ltd, pp 431-434 Candida antarctica lipase $\mathrm{B}$ in a hydrophilic organic solvent. J Biotechnol 163:346-352. doi: 10.1016/j.jbiotec.2012.11.006 
421 Park HJ, Joo JC, Park K, Yoo YJ (2012) Stabilization of Candida antarctica lipase B in hydrophilic organic solvent 422 by rational design of hydrogen bond. Biotechnol Bioprocess Eng 17:722-728. doi: 10.1007/s12257-012-0092$423 \quad 4$

424 Park HJ, Park K, Yoo YJ (2013b) Understanding the effect of tert-butanol on Candida antarctica lipase B using 425 molecular dynamics simulations. Mol Simul 39:653-659. doi: 10.1080/08927022.2012.758850

426 Pelton JT, McLean LR (2000) Spectroscopic Methods for Analysis of Protein Secondary Structure. Anal Biochem 427 277:167-176. doi: 10.1006/ABIO.1999.4320

428 Reetz MT, Carballeira JD, Vogel A (2006) Iterative saturation mutagenesis on the basis of b factors as a strategy for 429 increasing protein thermostability. Angew Chemie - Int Ed 45:7745-7751. doi: 10.1002/anie.200602795

430 Reetz MT, Soni P, Fernández L, et al (2010) Increasing the stability of an enzyme toward hostile organic solvents by 431 directed evolution based on iterative saturation mutagenesis using the B-FIT method. Chem Commun (Camb) $432 \quad 46: 8657-8658$. doi: $10.1039 / \mathrm{c} 0 \mathrm{cc} 02657 \mathrm{c}$

433 Ringborg RH, Woodley JM (2016) The application of reaction engineering to biocatalysis. React Chem Eng 1:1022. doi: $10.1039 / \mathrm{C} 5 \mathrm{RE} 00045 \mathrm{~A}$

435 Salihu A, Alam MZ (2015) Solvent tolerant lipases: A review. Process Biochem 50:86-96. doi: $436 \quad$ 10.1016/j.procbio.2014.10.019

437 Sandoval GC, Marty A, Condoret J-S (2001) Thermodynamic activity-based enzyme kinetics: Efficient tool for 438 nonaqueous enzymology. AIChE J 47:718-726. doi: 10.1002/aic.690470318

439 Schulze B, Klibanov AM (1991) Inactivation and stabilization of stabilisins in neat organic solvents. Biotechnol $440 \quad$ Bioeng 38:1001-1006. doi: 10.1002/bit.260380907

441 Sharma S, Kanwar SS (2014) Organic solvent tolerant lipases and applications. ScientificWorldJournal $442 \quad$ 2014:625258. doi: $10.1155 / 2014 / 625258$

443 Tamilarasan K, Kumar MD (2012) Biocatalysis and Agricultural Biotechnology Purification and characterization of 444 solvent tolerant lipase from Bacillus sphaericus MTCC 7542. Biocatal Agric Biotechnol 1:309-313. doi: $445 \quad 10.1016 /$ j.bcab.2012.07.001

446 Tao J, Kazlauskas RJ (Romas J. (2011) Biocatalysis for green chemistry and chemical process development. John $447 \quad$ Wiley \& Sons

448 Timasheff SN (1993) The Control of Protein Stability and Association by Weak Interactions with Water: How Do 
Tufvesson P, Lima-Ramos J, Haque N Al, et al (2013) Advances in the process development of biocatalytic processes. Org Process Res Dev 17:1233-1238. doi: 10.1021/op4001675

Villeneuve P, Muderhwa JM, Graille J, Haas MJ (2000) Customizing lipases for biocatalysis: a survey of chemical, physical and molecular biological approaches. J Mol Catal B Enzym 9:113-148. doi: 10.1016/S1381-

Wang S, Meng X, Zhou H, et al (2016) Enzyme Stability and Activity in Non-Aqueous Reaction Systems: A Mini

Wen S, Tan T, Zhao H (2013) Improving the thermostability of lipase Lip2 from Yarrowia lipolytica. J Biotechnol Review. Catalysts 6:32. doi: 10.3390/catal6020032 164:248-253. doi: 10.1016/j.jbiotec.2012.08.023

Wenda S, Illner S, Mell A, Kragl U (2011) Industrial biotechnology — the future of green chemistry? Green Chem 13:3007. doi: $10.1039 / \mathrm{c} 1 \mathrm{gc} 15579 \mathrm{~b}$

Xun E, Wang J, Zhang H, et al (2013) Resolution of N-hydroxymethyl vince lactam catalyzed by lipase in organic solvent. J Chem Technol Biotechnol 88:904-909. doi: 10.1002/jctb.3919

Yagonia CFJ, Park HJ, Hong SY, Yoo YJ (2015) Simultaneous improvements in the activity and stability of Candida antarctica lipase B through multiple-site mutagenesis. Biotechnol Bioprocess Eng 20:218-224. doi: $10.1007 / \mathrm{s} 12257-014-0706-0$

Yang C, Wang F, Lan D, et al (2012) Effects of organic solvents on activity and conformation of recombinant Candida antarctica lipase A produced by Pichia pastoris

Yang S, Zhou L, Tang H, et al (2002) Rational design of a more stable penicillin G acylase against organic cosolvent. J Mol Catal B Enzym 18:285-290. doi: 10.1016/S1381-1177(02)00108-X

Yao C, Cao Y, Wu S, et al (2013) An organic solvent and thermally stable lipase from Burkholderia ambifaria YCJ01: Purification, characteristics and application for chiral resolution of mandelic acid. J Mol Catal B

474 Yedavalli P, Madhusudhana Rao N (2013) Engineering the loops in a lipase for stability in DMSO. Protein Eng Des Sel 26:317-324. doi: 10.1093/protein/gzt002

476 YooPark HJ, Park K, Je Y (2013) Understanding the effect of tert-butanol on Candida antarctica lipase B using 
477 molecular dynamics simulations. Mol Simul 39:653-659

478 Yuan Z, Bailey TL, Teasdale RD (2005) Prediction of protein B-factor profiles. Proteins Struct Funct Bioinforma $479 \quad$ 58:905-912. doi: 10.1002/prot.20375

480 Zaks A, Klibanov AM (1984) Enzymatic catalysis in organic media at 100 degrees C. Science (80- ) 224:1249-1251. $481 \quad$ doi: $10.1126 /$ science.6729453

482 
Table 1 Selected solvent stable lipases incubated in solvent at different times and temperatures.

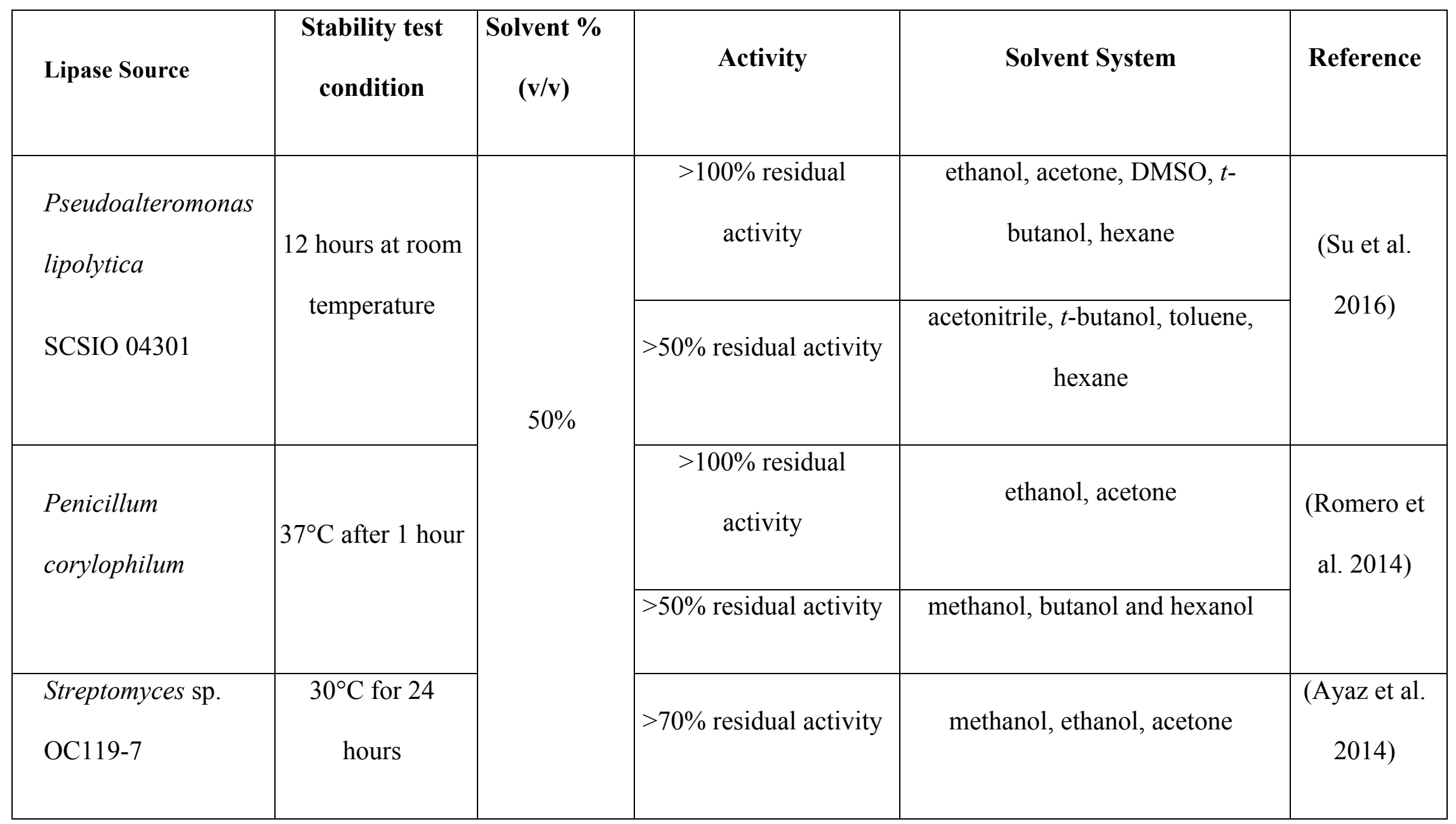




\begin{tabular}{|c|c|c|c|c|c|}
\hline Idiomarina sp. W33 & $30^{\circ} \mathrm{C}$ for 12 days & & $>70 \%$ residual activity & $\begin{array}{l}\text { toluene, cyclohexane, } n \text {-hexane, } 1 \text { - } \\
\text { decanol and isooctane }\end{array}$ & $\begin{array}{l}\text { (Li et al. } \\
\text { 2014) }\end{array}$ \\
\hline \multirow[t]{2}{*}{$\begin{array}{l}\text { Haloarcula sp. } \\
\text { IG41 }\end{array}$} & \multirow[t]{2}{*}{$\begin{array}{c}30^{\circ} \mathrm{C} \text { for } 2 \text { and } 5 \\
\text { days }\end{array}$} & & $>70 \%$ residual activity & $\begin{array}{l}\text { toluene, cyclohexane, } n \text {-hexane, } 1 \text { - } \\
\text { decanol and isooctane }\end{array}$ & \multirow[t]{2}{*}{$\begin{array}{l}\text { (Li \& Yu } \\
\text { 2014) }\end{array}$} \\
\hline & & & $>60 \%$ residual activity & chloroform and n-hexane & \\
\hline $\begin{array}{l}\text { Staphylococcus } \\
\text { aureus ALA1 }\end{array}$ & $30 \mathrm{~min}$ at $37^{\circ} \mathrm{C}$ & & $>90 \%$ residual activity & $\begin{array}{l}\text { acetone, benzene, ethanol, } \\
\text { methanol, 2-propanol and toluene }\end{array}$ & $\begin{array}{l}\text { (Ben Bacha } \\
\text { et al. 2016) }\end{array}$ \\
\hline \multirow[b]{2}{*}{ Bacillus sp. } & & $25 \%$ & $>80 \%$ relative activity & acetone, $t$-butanol & \multirow{2}{*}{$\begin{array}{l}\text { (Sivaramakri } \\
\text { shnan \& } \\
\text { Incharoensa } \\
\text { kdi 2016) }\end{array}$} \\
\hline & $30 \mathrm{~min}$ at $37^{\circ} \mathrm{C}$ & & $\sim 100 \%$ relative activity & methanol and ethanol & \\
\hline Staphylococcus & $30 \mathrm{~min}$ at room & & $>120 \%$ residual & Diethyl ether, DMSO & (Kamarudin \\
\hline
\end{tabular}




\begin{tabular}{|c|c|c|c|c|c|}
\hline \multirow[t]{2}{*}{ epidermidis AT2 } & \multirow[t]{2}{*}{ temperature } & & activity & & \multirow[t]{2}{*}{ et al. 2014) } \\
\hline & & & $\begin{array}{c}\sim 100 \% \text { residual } \\
\text { activity }\end{array}$ & $n$-hexane, toluene, acetone & \\
\hline \multirow{2}{*}{$\begin{array}{l}\text { Burkholderia } \\
\text { cepacia RQ3 }\end{array}$} & \multirow{2}{*}{$\begin{array}{c}40^{\circ} \mathrm{C} \text { for several } \\
\text { days }\end{array}$} & & half-life $>10$ days & isopropanol, ethanol and $n$-octane & \multirow{2}{*}{$\begin{array}{l}\text { (Xie et al. } \\
\text { 2016) }\end{array}$} \\
\hline & & & half-life of 6 days & DMSO & \\
\hline \multirow{4}{*}{$\begin{array}{l}\text { Aneurinibacillus } \\
\text { thermoaerophilus }\end{array}$} & \multirow{4}{*}{$\begin{array}{l}\text { 30min of } \\
\text { incubation }\end{array}$} & & $>60 \%$ relative activity & propyl acetate, $p$-xylene & \multirow{4}{*}{$\begin{array}{l}\text { (Masomian } \\
\text { et al. 2013) }\end{array}$} \\
\hline & & & & & \\
\hline & & & $>80 \%$ relative activity & toluene, benzene, 1-propanol & \\
\hline & & & $>100 \%$ relative activity & DMSO and methanol & \\
\hline $\begin{array}{l}\text { Xanthomonas } \\
\text { oryzae }\end{array}$ & $\begin{array}{c}70^{\circ} \mathrm{C} \text { for } 24 \\
\text { hours }\end{array}$ & $20 \%$ & $\begin{array}{l}\text { Specific activity of } \\
\qquad>250 \mathrm{U} / \mathrm{mg}\end{array}$ & heptane, hexane, methanol & $\begin{array}{l}\text { (Mo et al. } \\
\text { 2016) }\end{array}$ \\
\hline Aureobasidium & $30 \mathrm{~min}$ at $37^{\circ} \mathrm{C}$ & $10 \%$ & $>80 \%$ relative activity & methanol, acetonitrile, ethanol and & (Wongwatan \\
\hline
\end{tabular}




\begin{tabular}{|l|l|l|l|l|l|}
\hline melanogenum & $\begin{array}{c}\text { followed by } 24 \\
\text { hours at } 4{ }^{\circ} \mathrm{C}\end{array}$ & & & chloroform & apaiboon et \\
aseudomonas $\mathrm{sp}$. & $37^{\circ} \mathrm{C}$ for 4 hours & $5 \%$ & $>30 \%$ residual activity & ethanol, isopropanol, acetone & (Vrutika et \\
DMVR46 & & & & al. 2014) \\
\hline
\end{tabular}


Table 2 Lipase engineering towards improved organic solvent stability. Studies are categorised based on type of mutation: random, surface or flexible residues. The lipase, its mutation(s), the solvent system (and $\log \mathrm{P}$ value) are shown.

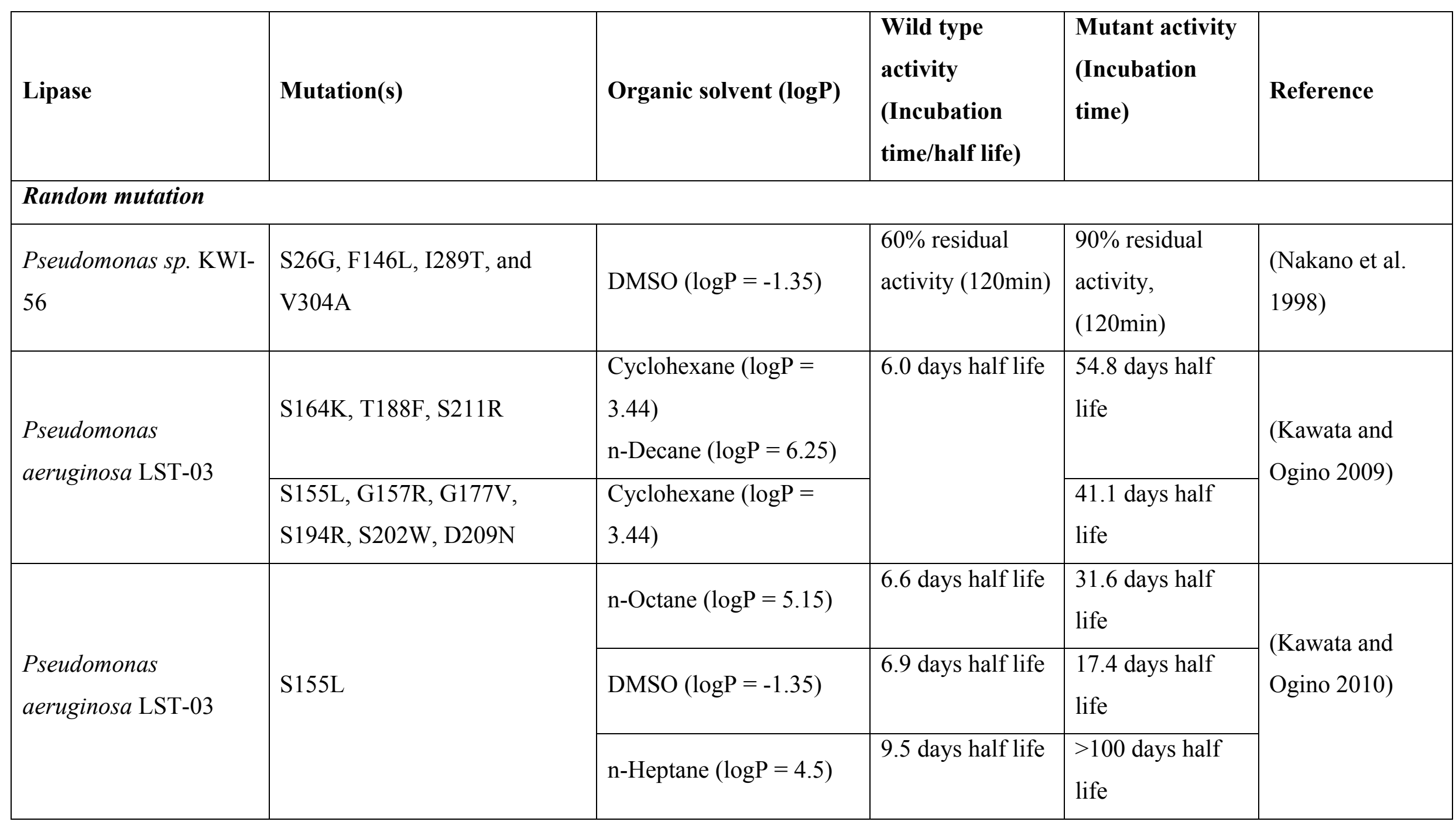




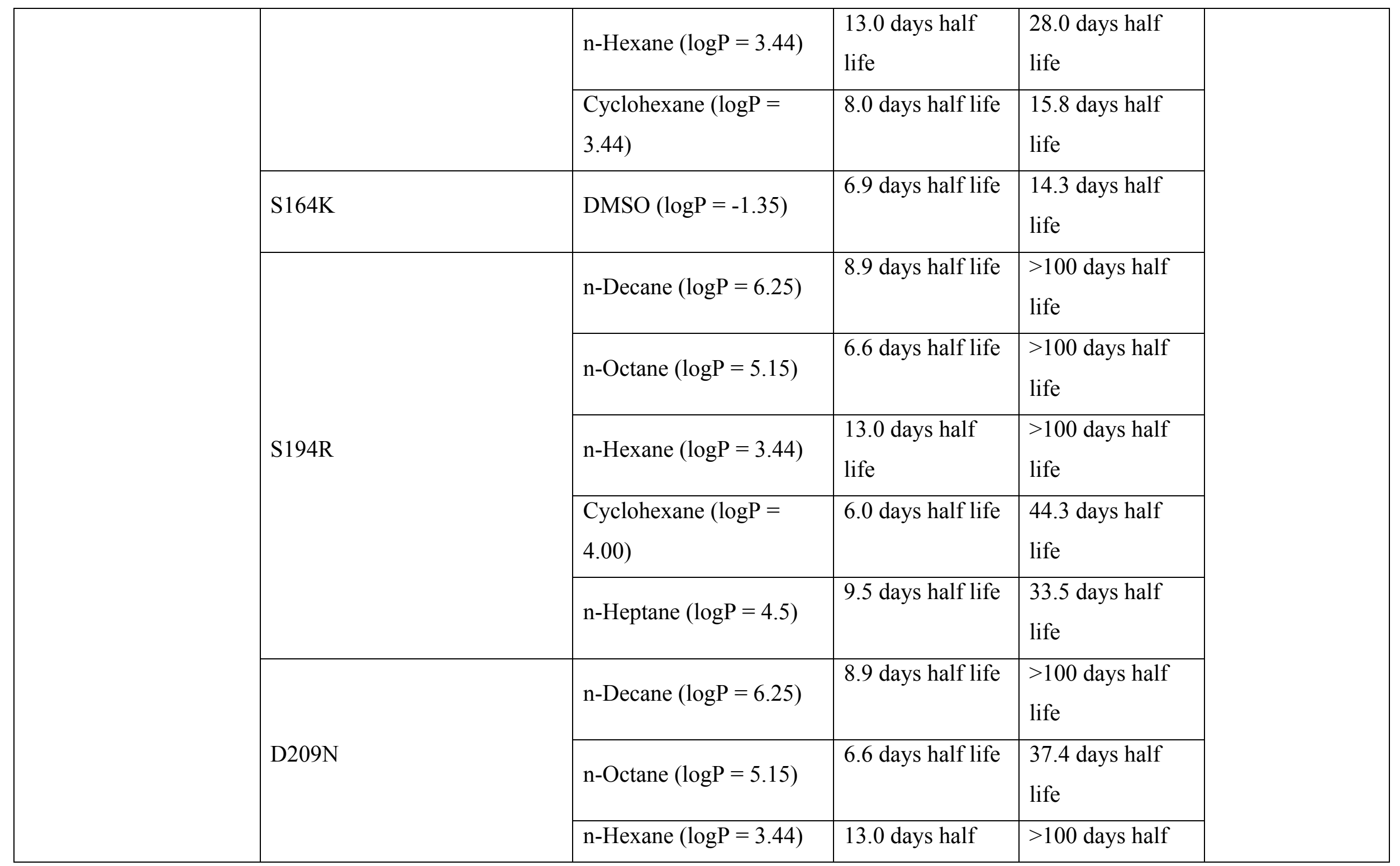




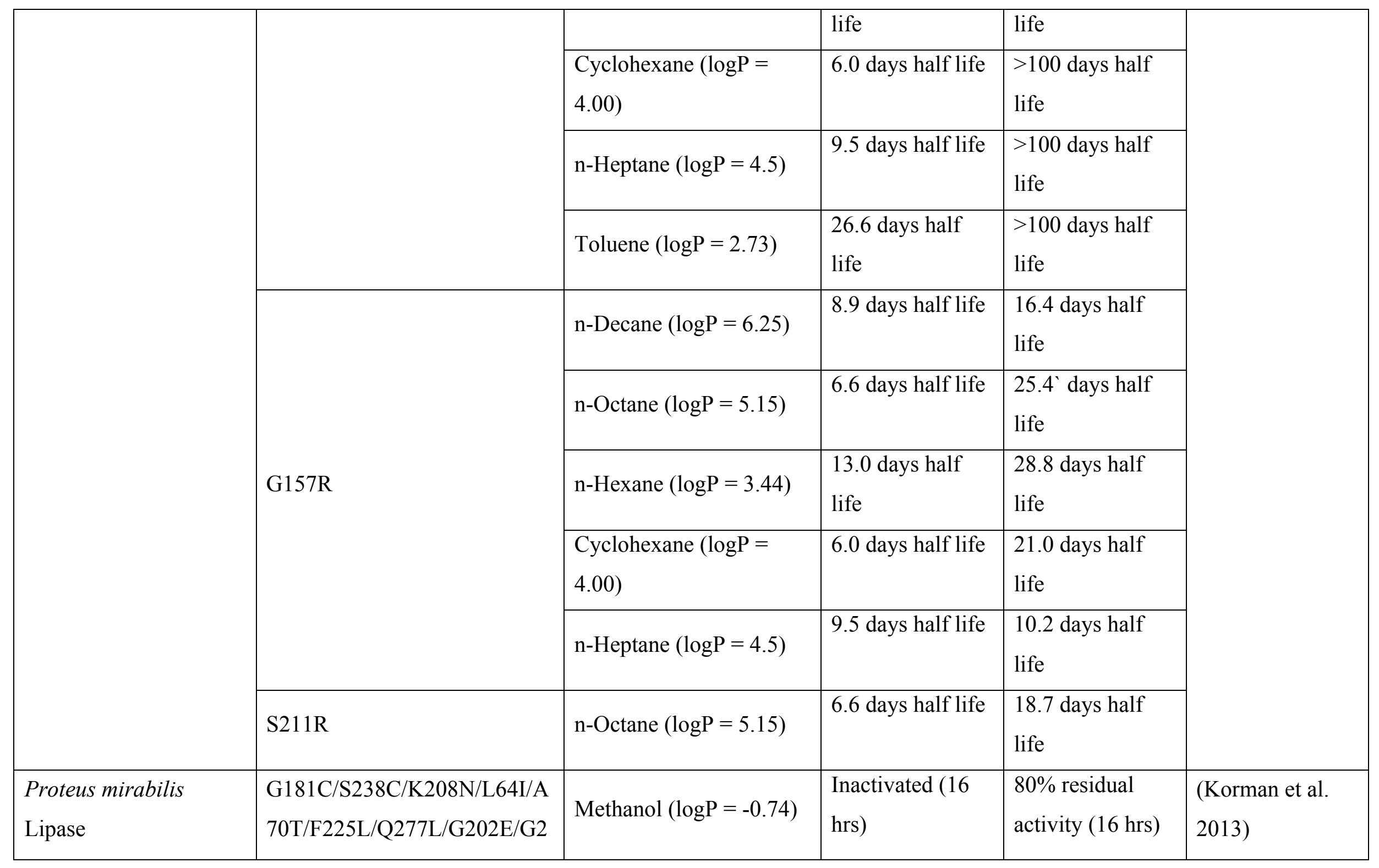




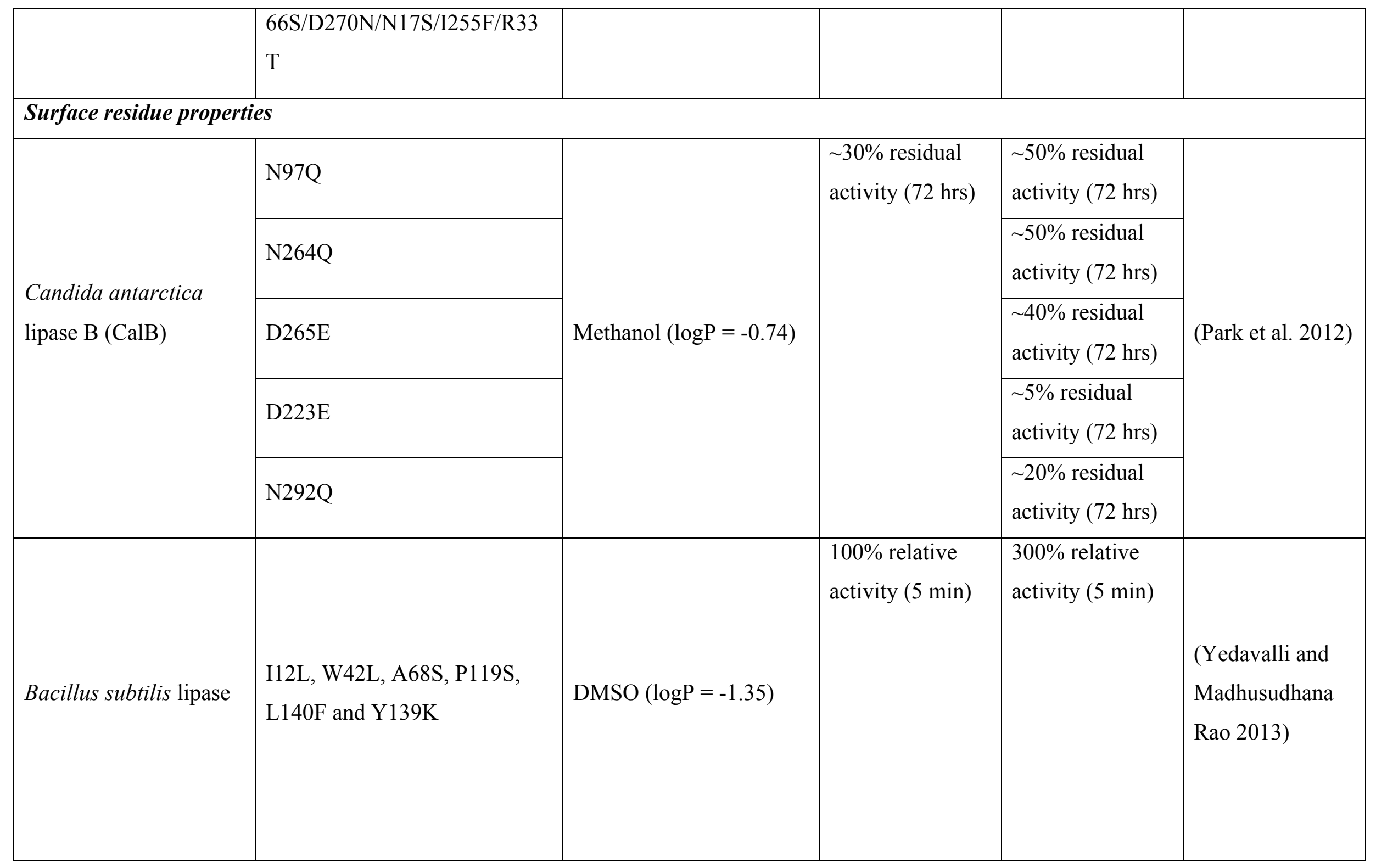




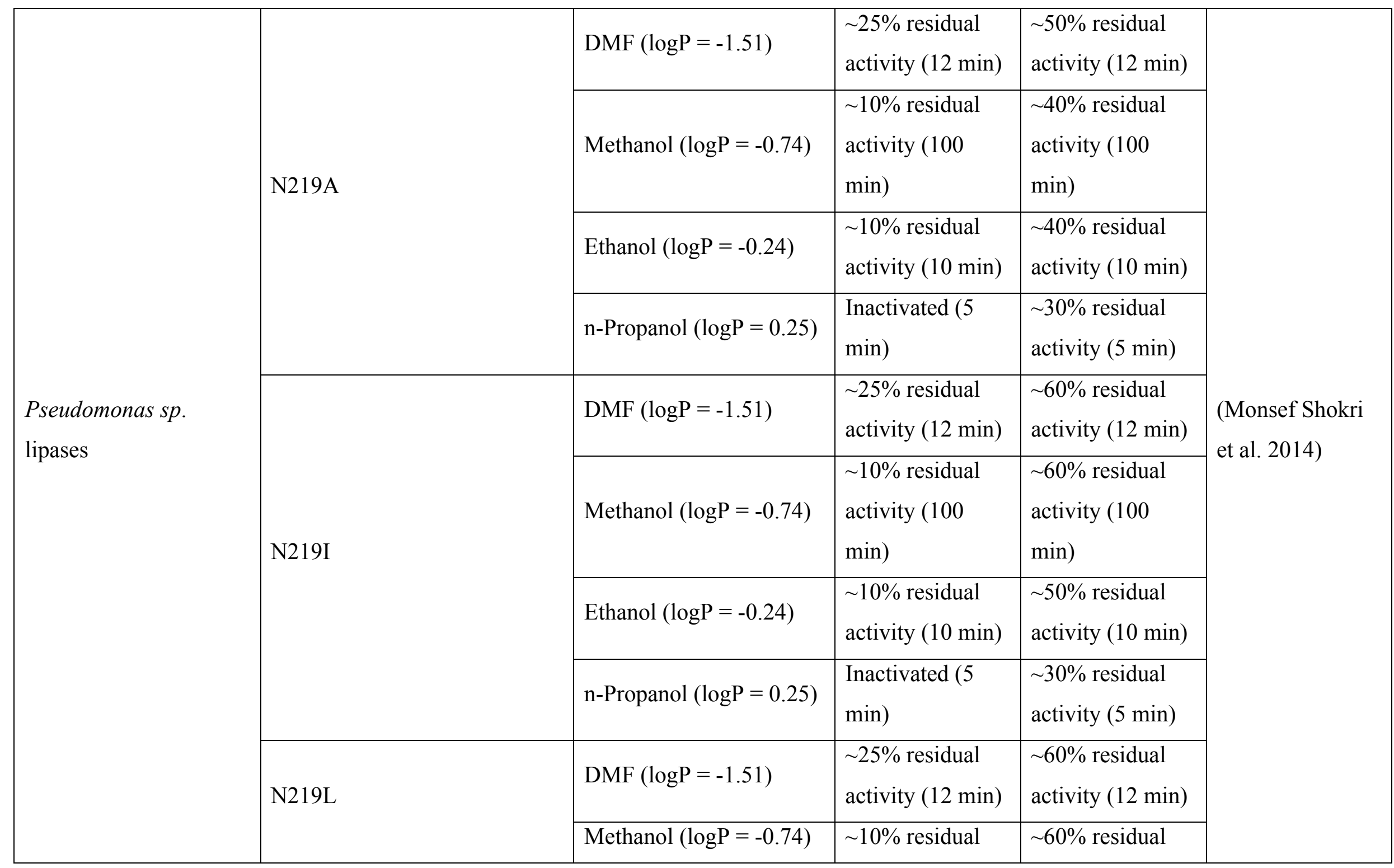




\begin{tabular}{|c|c|c|c|c|c|}
\hline & & & $\begin{array}{l}\text { activity }(100 \\
\min )\end{array}$ & $\begin{array}{l}\text { activity }(100 \\
\min )\end{array}$ & \\
\hline & & Ethanol $(\log \mathrm{P}=-0.24)$ & $\begin{array}{l}\sim 10 \% \text { residual } \\
\text { activity }(10 \mathrm{~min})\end{array}$ & $\begin{array}{l}60 \% \text { residual } \\
\text { activity }(10 \mathrm{~min})\end{array}$ & \\
\hline & & n-Propanol $(\log \mathrm{P}=0.25)$ & $\begin{array}{l}\text { Inactivated (5 } \\
\min )\end{array}$ & $\begin{array}{l}\sim 60 \% \text { residual } \\
\text { activity }(5 \mathrm{~min})\end{array}$ & \\
\hline \multirow{4}{*}{$\begin{array}{l}\text { Geobacillus } \\
\text { stearothermophilus T6 } \\
\text { Lipase }\end{array}$} & Q185L & \multirow{4}{*}{ Methanol $(\log \mathrm{P}=-0.74)$} & \multirow{4}{*}{2.9 min half life } & 77 min half life & \multirow{4}{*}{$\begin{array}{l}\text { (Dror et al. 2015) } \\
\text { (Dror et al. 2014) }\end{array}$} \\
\hline & H86Y/A269T & & & 116 min half life & \\
\hline & Q185L/A269T & & & $231 \mathrm{~min}$ half life & \\
\hline & H86Y/A269T/ R374W & & & 347 min half life & \\
\hline \multirow{5}{*}{$\begin{array}{l}\text { Bacillus subtilis } \\
\text { Lipase }\end{array}$} & M134D & DMSO $(\log \mathrm{P}=-1.35)$ & $<10$ hrs half life & $<25$ hrs half life & \multirow{5}{*}{$\begin{array}{l}\text { (Reetz et al. } \\
\text { 2010) }\end{array}$} \\
\hline & & $\mathrm{DMF}(\log \mathrm{P}=-1.51)$ & $<10$ hrs half life & $<25$ hrs half life & \\
\hline & \multirow{3}{*}{ M134D/I157M } & $\begin{array}{l}\text { Acetonitrile }(\log \mathrm{P}=- \\
0.34)\end{array}$ & $\begin{array}{l}<30 \text { mins half } \\
\text { life }\end{array}$ & $\begin{array}{l}>300 \text { mins half } \\
\text { life }\end{array}$ & \\
\hline & & DMSO $(\log \mathrm{P}=-1.35)$ & $<10 \mathrm{hrs}$ half life & $<50$ hrs half life & \\
\hline & & DMF $(\log \mathrm{P}=-1.51)$ & $<10$ hrs half life & $<25$ hrs half life & \\
\hline
\end{tabular}




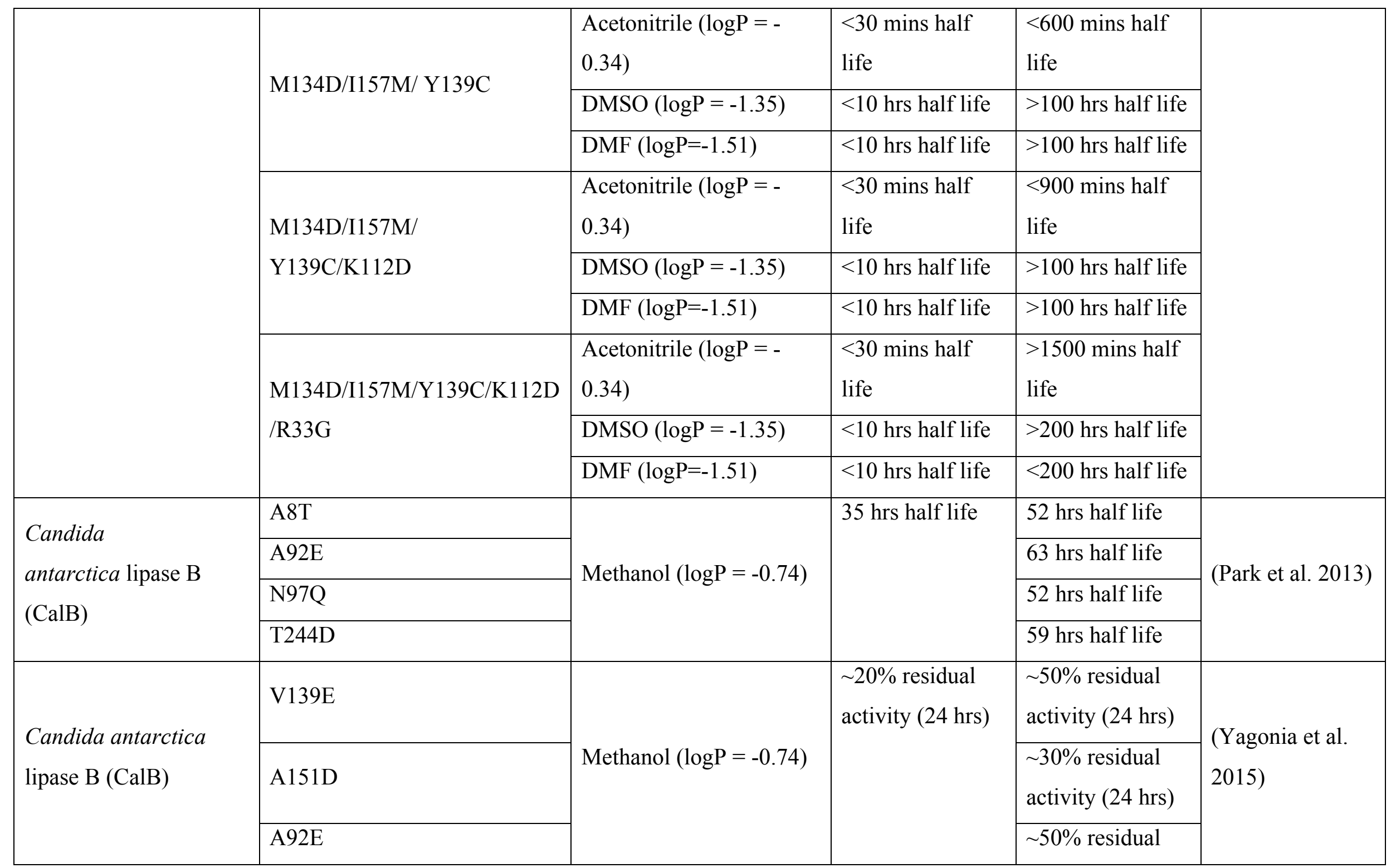




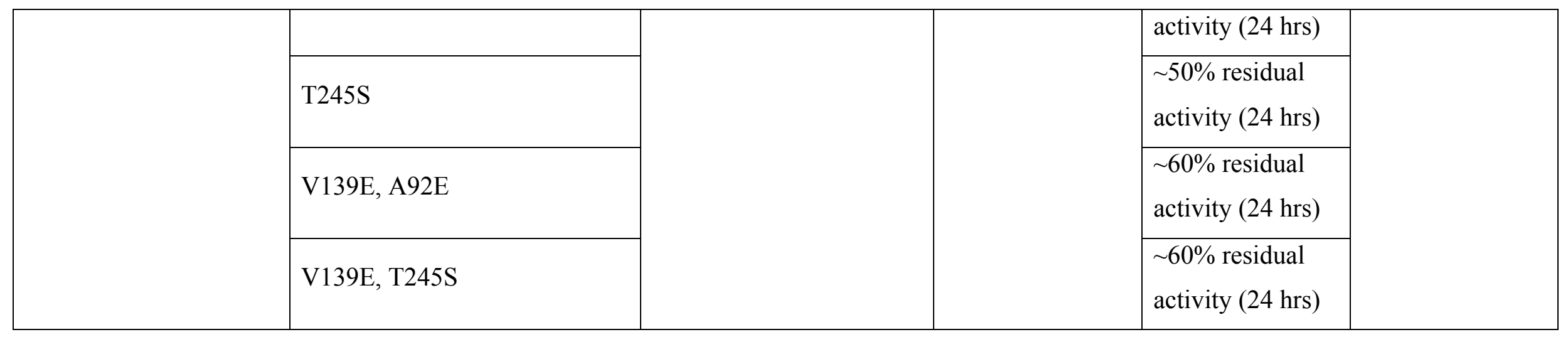


Table 3 Lipases commonly used in the food industry for the production of food flavours and aromas. The table shows lipase source, the product of the lipase catalysed reaction along with the solvent system employed for synthesis and typical yields.

\begin{tabular}{|c|c|c|c|c|c|}
\hline $\begin{array}{l}\text { Lipase } \\
\text { Source }\end{array}$ & $\begin{array}{l}\text { Product } \\
\text { (application) }\end{array}$ & Lipase state & Yield & $\begin{array}{l}\text { Solvent } \\
\text { system }\end{array}$ & Reference \\
\hline $\begin{array}{l}\text { Aspergillus } \\
\text { oryzae }\end{array}$ & $\begin{array}{l}\text { Cis-3-hexen- } \\
\text { 1-yl-acetate } \\
\text { (fresh/floral } \\
\text { odour) }\end{array}$ & $\begin{array}{l}\text { In dry } \\
\text { mycelium }\end{array}$ & $98 \%$ & $\begin{array}{l}60 \mathrm{mM} \text { acetic } \\
\text { acid and cis-3- } \\
\text { hexen-1-ol }\end{array}$ & $\begin{array}{l}\text { Kirdi et al. } \\
2017\end{array}$ \\
\hline $\begin{array}{l}\text { Pseudomonas } \\
\text { cepacia }\end{array}$ & $\begin{array}{l}\text { Cinnamyl } \\
\text { Propionate } \\
\text { (spicy floral } \\
\text { flavour) }\end{array}$ & $\begin{array}{l}\text { Immobilized } \\
\text { on } \\
\text { hydroxylpropyl } \\
\text { methyl } \\
\text { cellulose and } \\
\text { polyvinyl } \\
\text { alcohol }\end{array}$ & $\begin{array}{l}>50 \%, \\
<80 \%\end{array}$ & $\begin{array}{l}\text { Cinnamyl } \\
\text { alcohol: vinyl } \\
\text { propionate } \\
(1: 2) \text { with } 1 \mathrm{ml} \\
n \text {-hexane or } \\
\text { and toluene } \\
\text { (non-polar } \\
\text { solvents) }\end{array}$ & $\begin{array}{l}\text { Badgujar } \\
\text { et al. } 2016\end{array}$ \\
\hline
\end{tabular}




\begin{tabular}{|c|c|c|c|c|c|}
\hline & & & & solvents & \\
\hline $\begin{array}{l}\text { Thermomyces } \\
\text { lanuginosus }\end{array}$ & $\begin{array}{l}\text { Butyl } \\
\text { butyrate } \\
\text { (pineapple } \\
\text { flavour) }\end{array}$ & $\begin{array}{l}\text { Immobilised } \\
\text { on immobeads } \\
150\end{array}$ & $84 \%$ & $\begin{array}{l}\text { butanol:butyric } \\
\text { acid, 3:1 }\end{array}$ & $\begin{array}{l}\text { Matte et } \\
\text { al. } 2016\end{array}$ \\
\hline $\begin{array}{l}\text { Bacillus } \\
\text { aerius }\end{array}$ & $\begin{array}{l}\text { Isoamyl } \\
\text { acetate } \\
\text { (pear/banana } \\
\text { flavour) }\end{array}$ & $\begin{array}{l}\text { Immobilised } \\
\text { on silica gel } \\
\text { matrix }\end{array}$ & $68 \%$ & $\begin{array}{l}\text { 1:1 ratio of } \\
\text { acetic acid and } \\
\text { isoamyl } \\
\text { alcohol }\end{array}$ & $\begin{array}{l}\text { Narwal et } \\
\text { al. } 2016\end{array}$ \\
\hline \multirow{2}{*}{$\begin{array}{l}\text { Bacillus } \\
\text { licheniformis }\end{array}$} & $\begin{array}{l}\text { Ethyl lactate } \\
\text { (fruity odour } \\
\text { and fruity } \\
\text { flavour) }\end{array}$ & \multirow{2}{*}{$\begin{array}{l}\text { Immobilized } \\
\text { on magnetite } \\
\text { particles }\end{array}$} & $23 \%$ & $\begin{array}{l}\text { (1:1) ethyl } \\
\text { alcohol and } \\
\text { lactic acid }\end{array}$ & \multirow{2}{*}{$\begin{array}{l}\text { Jain \& } \\
\text { Mishra, } \\
2015\end{array}$} \\
\hline & $\begin{array}{l}\text { Isobutyl } \\
\text { acetate } \\
\text { (pineapple } \\
\text { flavour) }\end{array}$ & & $36 \%$ & $\begin{array}{l}\text { isobutyl } \\
\text { alcohol and } \\
\text { acetic acid } \\
(1: 1)\end{array}$ & \\
\hline $\begin{array}{l}\text { Candida } \\
\text { rugosa }\end{array}$ & $\begin{array}{l}\text { Ethyl } \\
\text { caprylate } \\
\text { (flavour } \\
\text { ester) }\end{array}$ & $\begin{array}{l}\text { Immobilised } \\
\text { on exfoliated } \\
\text { graphene oxide }\end{array}$ & $85 \%$ & $\begin{array}{l}\text { ethanol and } \\
\text { cyclo-octane } \\
(0.15: 0.1 \mathrm{M})\end{array}$ & $\begin{array}{l}\text { Patel et al. } \\
2015\end{array}$ \\
\hline Pseudomonas & Ethyl & Immobilised & $81 \%$ & Ethanol/butyric & Vrutika \& \\
\hline
\end{tabular}




\begin{tabular}{|c|c|c|c|c|c|}
\hline$s p$. DMRV46 & $\begin{array}{l}\text { butyrate } \\
\text { (tropical fruit } \\
\text { flavour) }\end{array}$ & $\begin{array}{l}\text { on multi- } \\
\text { walled carbon } \\
\text { nanotubes }\end{array}$ & & $\begin{array}{l}\text { acid and n- } \\
\text { heptane } \\
(0.15: 0.2 \mathrm{M})\end{array}$ & $\begin{array}{l}\text { Datta, } \\
2015\end{array}$ \\
\hline $\begin{array}{l}\text { Pseudomonas } \\
\text { sp. DMVR46 }\end{array}$ & $\begin{array}{l}\text { Pentyl } \\
\text { valerate } \\
\text { (fruity } \\
\text { aroma) }\end{array}$ & $\begin{array}{l}\text { Immobilisation } \\
\text { into AOT- } \\
\text { organogels }\end{array}$ & $88 \%$ & $\begin{array}{l}\text { pentanol and } \\
\text { valeric acid } \\
(1: 1)\end{array}$ & $\begin{array}{l}\text { Vrutika et } \\
\text { al. } 2014\end{array}$ \\
\hline $\begin{array}{l}\text { Bacillus } \\
\text { safensis }\end{array}$ & $\begin{array}{l}\text { Ethyl laurate } \\
\text { (waxy odour } \\
\text { and flavour) }\end{array}$ & $\begin{array}{l}\text { Purified } \\
\text { enzyme }\end{array}$ & $80 \%$ & $\begin{array}{l}\text { lauric acid and } \\
\text { ethanol }(1: 1)\end{array}$ & $\begin{array}{l}\text { Kumar et } \\
\text { al. } 2014\end{array}$ \\
\hline $\begin{array}{l}\text { Candida } \\
\text { rugosa }\end{array}$ & $\begin{array}{l}\text { Vitamin E } \\
\text { succinate } \\
\text { (food } \\
\text { supplement) }\end{array}$ & $\begin{array}{l}\text { Purified } \\
\text { Enzyme }\end{array}$ & $47 \%$ & $\begin{array}{l}\text { 1:5 (substrate: } \\
\text { DMSO) }\end{array}$ & $\begin{array}{l}\text { X. jun } \\
\text { Jiang et al. } \\
2013\end{array}$ \\
\hline
\end{tabular}


Table 4 Pharmaceutical products synthesized by lipases in a solvent system. The table shows the product formed throughed the lipase catalysed reaction as well as its application, the lipase invovled and the mode of operation including the solvent system.

\begin{tabular}{|c|c|c|c|c|c|c|}
\hline \multicolumn{2}{|c|}{ Product } & Application & Lipase & Lipase state & Solvent system & Reference \\
\hline \multicolumn{2}{|c|}{ (R)-Indano } & $\begin{array}{l}\text { Precursor of drugs } \\
\text { (Sertraline, Indinavir, } \\
\text { Irindalone, Rasagiline } \\
\text { mesilate) }\end{array}$ & Candida antarctica & $\begin{array}{l}\text { Immobilized on Cashew } \\
\text { apple bagasse support }\end{array}$ & $\begin{array}{l}\text { Toluene and } \\
\text { diisopropyl } \\
\text { ether }\end{array}$ & $\begin{array}{c}\text { De Souza et } \\
\text { al. } 2016\end{array}$ \\
\hline \multirow{4}{*}{$\begin{array}{l}\text { Sugar } \\
\text { Fatty } \\
\text { Acid } \\
\text { Ester }\end{array}$} & $\begin{array}{l}\text { 6-O-glucose } \\
\text { tetradecanoate }\end{array}$ & \multirow{4}{*}{$\begin{array}{c}\text { Food, } \\
\text { Pharmaceuticals, } \\
\text { cosmetic, } \\
\text { insecticidal, } \\
\text { antimicrobial, oral } \\
\text { care uses }\end{array}$} & $\begin{array}{c}\text { Candida antarctica } \\
\text { Sp-435 }\end{array}$ & $\begin{array}{c}\text { Immobilized lipase } \\
\text { Novozym435 }\end{array}$ & $\begin{array}{l}\text { Dimethylforma } \\
\text { mide }\end{array}$ & $\begin{array}{c}\text { Degn et al. } \\
1999\end{array}$ \\
\hline & $\begin{array}{l}\text { 6-O-glucose } \\
\text { octadecanoate }\end{array}$ & & Mucor meihei & $\begin{array}{l}\text { Immobilized from } \\
\text { NOVO industries }\end{array}$ & Heptane & $\begin{array}{l}\text { Oguntimein } \\
\text { et al. } 1993\end{array}$ \\
\hline & $\begin{array}{c}\text { 6-O-acetyl } \\
\text { glucopyranosi } \\
\text { de }\end{array}$ & & $\begin{array}{c}\text { Porcine pancreatic } \\
\text { lipase IIII }\end{array}$ & Free enzyme & Hexane & \begin{tabular}{|c} 
Sharma \& \\
Chattopadhya \\
y 1993
\end{tabular} \\
\hline & $\begin{array}{l}\text { Dilauroyl } \\
\text { maltose }\end{array}$ & & Candida antarctica & $\begin{array}{c}\text { Immobilized by Novo- } \\
\text { Nordisk }\end{array}$ & $\begin{array}{l}\text { Acetone and } n- \\
\text { hexane }\end{array}$ & Jia et al. 2010 \\
\hline
\end{tabular}




\begin{tabular}{|c|c|c|c|c|c|}
\hline $\begin{array}{c}\text { Fructose } \\
\text { Oleate }\end{array}$ & & $\begin{array}{c}\text { Thermomyces } \\
\text { lanuginosus and } \\
\text { Pseudomonas } \\
\text { fluorescens }\end{array}$ & $\begin{array}{l}\text { Immobilized on } \\
\text { functionalized silica }\end{array}$ & $t$-butyl alcohol & $\begin{array}{c}\text { Vescovi et al. } \\
2017\end{array}$ \\
\hline Phytosterols & $\begin{array}{c}\text { Cholesterol } \\
\text { reduction, anti-viral } \\
\text { and anti- } \\
\text { inflammatory }\end{array}$ & Candida rugosa & $\begin{array}{c}\text { Immobilized on } \\
\text { macroporous acrylic } \\
\text { resin }\end{array}$ & $n$-Hexane & $\begin{array}{c}\text { Jiang et al. } \\
2013\end{array}$ \\
\hline (R,S)-1-phenylethanol & $\begin{array}{l}\text { cosmetics and the } \\
\text { pharmaceutical } \\
\text { industry }\end{array}$ & $\begin{array}{c}\text { Pseudomonas } \\
\text { stutzeri }\end{array}$ & Free enzyme & $n$-hexane & $\begin{array}{l}\text { Cao et al. } \\
2012\end{array}$ \\
\hline
\end{tabular}

Table 5.2: Continued. 


\begin{tabular}{|c|c|c|c|c|c|}
\hline Product & Application & Lipase & Lipase state & Solvent system & Reference \\
\hline $\begin{array}{c}\text { Chiral mandelic acid and } \\
\text { its derivates }\end{array}$ & $\begin{array}{l}\text { Intermediates for } \\
\text { pharmaceutical } \\
\text { industry }\end{array}$ & Burkholderia ambifaria & Free enzyme & $\begin{array}{l}\text { Diisopropyl } \\
\text { ether }\end{array}$ & $\begin{array}{l}\text { Yao et al. } \\
2013\end{array}$ \\
\hline Ethyl oleate & $\begin{array}{l}\text { Solvent for } \\
\text { preparation of } \\
\text { steroids; } \\
\text { plasticizer }\end{array}$ & $\begin{array}{c}\text { Geobacillus } \\
\text { stearothermophilus }\end{array}$ & $\begin{array}{l}\text { Immobilized on } \\
\text { cellulosic nanogel }\end{array}$ & $\begin{array}{l}\text { Ethanol and } \\
\text { DMSO }\end{array}$ & $\begin{array}{l}\text { Kumar et } \\
\text { al. } 2015\end{array}$ \\
\hline$\beta$-sitostanol ester & $\begin{array}{l}\text { Decreasing } \\
\text { cholesterol } \\
\text { absorption }\end{array}$ & Ophiostoma piceae & Crude enzyme & Isooctane & $\begin{array}{c}\text { Molina- } \\
\text { Gutiérrez et } \\
\text { al. } 2016\end{array}$ \\
\hline
\end{tabular}




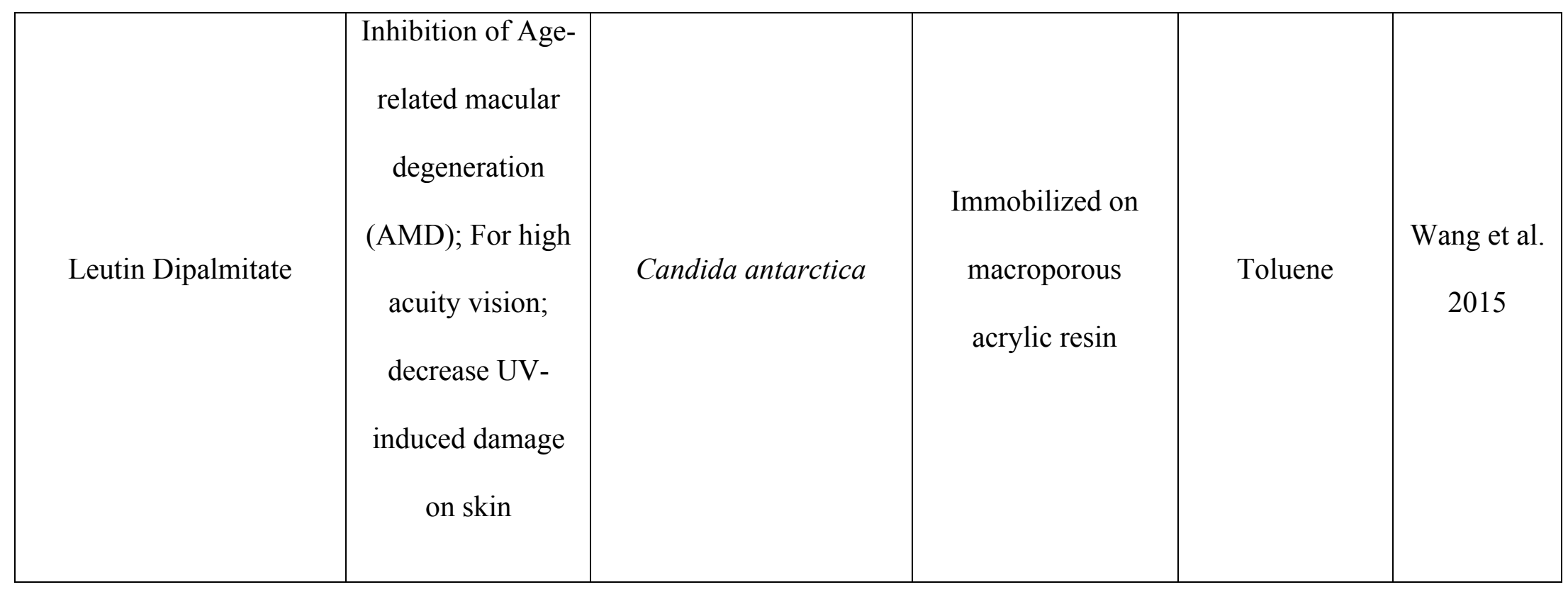


Table 5 Examples of the production and degradation of polymers by lipases. The source of the lipase, the state utilised and the substrate and solvent system employed are shown.

\begin{tabular}{|c|c|c|c|c|c|}
\hline Action & $\begin{array}{l}\text { Lipase } \\
\text { Source }\end{array}$ & $\begin{array}{c}\text { Lipase } \\
\text { state }\end{array}$ & Substrate & $\begin{array}{l}\text { Solvent } \\
\text { system }\end{array}$ & Reference \\
\hline \multirow{3}{*}{$\begin{array}{l}\text { Polyester } \\
\text { synthesis }\end{array}$} & $\begin{array}{l}\text { Yarrowia } \\
\text { lipolytica }\end{array}$ & $\begin{array}{l}\text { Immobiliz } \\
\text { ed on } \\
\text { microporo } \\
\text { us resin }\end{array}$ & $\beta$-caprolactone & Heptane & $\begin{array}{c}\text { Barrera- } \\
\text { rivera \& } \\
\text { Flores- } \\
\text { carreón } \\
2012\end{array}$ \\
\hline & $\begin{array}{l}\text { Candida } \\
\text { antarctica }\end{array}$ & $\begin{array}{l}\text { Immobiliz } \\
\text { ed on } \\
\text { nanoclays }\end{array}$ & $\beta$-caprolactone & $\begin{array}{l}\text { Dry } \\
\text { toluene }\end{array}$ & $\begin{array}{c}\text { Öztürk } \\
\text { Düşkünkor } \\
\text { ur et al. } \\
2014\end{array}$ \\
\hline & $\begin{array}{l}\text { Candida } \\
\text { antarctica }\end{array}$ & $\begin{array}{l}\text { Immobiliz } \\
\text { ed from } \\
\text { Novozym } \\
\text { e }\end{array}$ & $\begin{array}{l}\beta \text {-caprolactone and } \\
\beta \text {-thiocaprolactone }\end{array}$ & Toluene & $\begin{array}{l}\text { Duchiron } \\
\text { et al. } 2017\end{array}$ \\
\hline \multirow[t]{2}{*}{$\begin{array}{l}\text { Polymer } \\
\text { degradati }\end{array}$} & $\begin{array}{l}\text { Candida } \\
\text { antarctica }\end{array}$ & $\begin{array}{l}\text { Immobiliz } \\
\text { ed on } \\
\text { acrylic } \\
\text { resin } \\
\text { beads }\end{array}$ & $\begin{array}{c}\operatorname{Poly}(\beta- \\
\text { caprolactone })\end{array}$ & Toluene & $\begin{array}{l}\text { Aris et al. } \\
2016\end{array}$ \\
\hline & Bacillus & Free & Polyhydroxyalkano & Chlorofor & Kanmani \\
\hline
\end{tabular}




\begin{tabular}{|c|c|c|c|c|c|}
\hline & subtilis & enzyme & ates (PHAs) & $\mathrm{m}$ & et al. 2016 \\
\cline { 2 - 6 } & Lactobacill & Free & $\operatorname{Poly}(\beta-$ & Chlorofor & Khan et al. \\
plantarum & enzyme & caprolactone $)$ & $\mathrm{m}$ & 2017 \\
\hline
\end{tabular}

